\title{
Spontaneous Lesions in Cynomolgus Monkeys Used in Toxicity Studies
}

\author{
Takayasu ITO, Fumio CHATANI, Satoshi SASAKI, Takao ANDO, \\ and Hiroaki MIY AJIMA \\ Drug Safety Research Laboratories, Takeda Chemical Industries, Ltd., \\ 6-10-1 Himuro-cho, Takatsuki-shi, Osaka 569, Japan
}

(Received 10 December 1991/ Accepted 4 June 1992)

\begin{abstract}
Spontaneous lesions in wild-caught, laboratory-maintained cynomolgus monkeys used in drug-toxicity studies were examined histopathologically in an effort to better distinguish toxic changes from spontaneous lesions and assess the toxicity of drugs more exactly. In the liver and kidney, where toxic changes are observed frequently, many spontaneous lesions were observed. Infiltration of mononuclear cells, vacuolization of the hepatocytes, dilatation of the renal tubules, and vacuolization of the renal epithelia were observed at a relatively high frequency. It is considered important to examine these changes carefully, because they closely resemble the changes recognized as toxic. Deposition of brownish pigment was observed in various organs such as the liver, kidney, spleen, intestinal tract, lung and brain, however the type of pigment differed among the organs, and histochemical examination revealed anthracosis or accumulation of hemosiderin, or melanin. Since the monkeys were caught in the wild, many parasitic lesions were observed especially in the large intestine and liver. Helminthous worms were frequently observed in the granulomas in the large intestine, however no parasites were observed in the granulomas in the liver. Such lesions in the liver may be misinterpreted as toxic changes, when only scars or inflammatory lesions are observed. — KEY WORDS : cynomolgus monkeys, spontaneous lesions
\end{abstract}

In pre-clinical toxicity studies of new drug candidates for human use, the use of primates which closely resemble humans is important [35]. However, many monkeys used in toxicity studies have bacterial or parasitic lesions, because almost all are wild-caught. Therefore, the accumulation of background data in hematology, blood chemistry, and histopathology and the recognition of spontaneous lesions are very important. Cyomolgus monkeys (Macaca fascicularis), which have been caught in Indonesia, the Philipines, or Malaysia, are used in toxicity studies in our laboratories. Though there are several reports $[2,10,24,26,28,32]$ on the parasitic lesions in this animal, no histopathological background data have been reported.

In the present study, the histopathology of spontaneous lesions found in 442 cynomolgus monkeys (221 per sex) used in toxicity studies which were performed in our laboratories from 1979 through 1990 is described.

\section{Materials and Methods}

A. Animals : Four hundred and forty-two cynomolgus monkeys (221 per sex, assumed to be more than 3 years old, caught in Indonesia, the Philipines, or Malaysia) used in 17 toxicity studies performed in our laboratories from 1979 through 1990 were the subjects of this study. These animals were quarantined at CLEA Japan, Inc. after import and were confirmed to be normal by clinical observation, measurement of body weight, microbiological examinations (tuberculin reaction, serological examinations for Salmonella, Shigella, and Entoamoeba), parasitological examinations 
Table 1. Treatment-related lesions in cynomolgus monkeys examined in this study

\begin{tabular}{cl}
\hline Study No. & \\
\hline 1 & Dilatation of renal tubules \\
2 & None \\
3 & Vacuolization or hypertrophy of hepatocytes / Mulltinucleated hepatocytes \\
& Vacuolization or hypertrophy of renal tubular epithelia \\
4 & None \\
5 & Necrosis of hepatocytes / Necrosis or regeneration of renal tubular epithelia \\
6 & Infiltration of eosinophils in various organs \\
7 & Infiltration of eosinophils in various organs \\
8 & Necrosis of hepatocytes / Hypertrophy of germinal center of spleen \\
9 & Necrosis or vacuolization of hepatocytes / Hyaline deposition of renal tubular epithelia \\
10 & Pecrosis, vacuolization or pigmentation of hepatocytes \\
11 & Necrosis or vacuolization of hepatocytes \\
12 & Pigmentation of hepatocytes \\
13 & Necrosis, vacuolization, regeneration or hypertrophy of renal tubular epithelia \\
15 & Hypercellularity of bone marrow / Infiltration of eosinophils in various organs \\
16 & Congestion and follicular atrophy of spleen \\
& Atrophy or vacuolization of hepatocytes / Degeneration, regeneration or hyaline \\
17 & Heposition of renal tubular epithelia / Atrophy of myocardium / \\
\hline
\end{tabular}

(parasite-ova), hematological examinations (hematocrit value, leukocyte count), and blood chemistry (urea nitrogen, alanine aminotransferase, aspartate aminotransferase) in our laboratories.

The animals were housed in individual metal cages in an air-conditioned room with a temperature of $24 \pm 2{ }^{\circ} \mathrm{C}$, a relative humidity of $55 \pm 10 \%$, air-exchanges $10-20 \mathrm{times} / \mathrm{hr}$, and a $12 \mathrm{hr}$ fluorescent illumination light/dark cycle. Each animal was fed daily $150 \mathrm{~g}$ of a pellet diet (AB, Oriental Yeast Co., Ltd. or Certified Primate Chow (5048), Ralston Purina Co.) and was allowed free access to tap water.

B. Histopathology : At the end of the dosing period in each toxicity study, each animal was anesthetized with ketamine hydrochloride (Ketalar ${ }^{\circledR}$, Sankyo Co., Ltd.) and was sacrificed by bleeding from the common carotid artery. The following organs were observed visually and fixed in $10 \%$ neutral buffered formalin : liver, gallbladder, kidneys, heart, bronchus, lungs, spleen, trachea, tongue, esophagus, stomach, duodenum, small intestine, large intestine, submaxillary glands, sublingual glands, pancreas, thymus, mesenteric lymph node, bone marrow, testes, prostate, seminal vesicles, ovaries, uterus, vagina, urinary bladder, brain, spinal cord, lacrimal glands, pituitary, thyroids, parathyroids, adrenals, skin, mammary gland, sternum, and femurs. The eye balls were fixed in $4 \%$ glutaraldehyde and post-fixed in $5 \%$ neutral buffered formalin. All organs were embedded in paraffin, sectioned, and stained with hematoxylin and eosin $(\mathrm{H}-\mathrm{E})$. As a rule, a left organ of paired organs was examined. Pigments were differentiated by Berlin blue stain [7], Masson stain for argentophile granules [19], the ferrous ion uptake method for melanin [16], Nile blue stain for melanin [15], bleaching by potassium permanganate-oxalic acid [17], the periodic acidSchiff reation (PAS) [20], and observation of autofluorescence with ultraviolet radiation [34]. To identify the cells with pigment in the brain, immunohistochemistry against glial fibrillary acidic protein (GFAP) was performed using an immunoperoxidase staining kit (HistoScan, Biomeda Co., USA).

Findings other than the lesions shown in Table 1, which were considered to be treatmentrelated, were assumed to be spontaneous.

Differences between the sexes in the incidence of each lesion were statistically analyzed using the chi-square test. 
Table 2. Incidnce of spontaneous histopathological lesions in cynomolgus monkeys

\begin{tabular}{|c|c|c|}
\hline & Male $(\%)$ & Female $(\%)$ \\
\hline Liver & $\mathrm{n}=221$ & $\mathrm{n}=221$ \\
\hline Mononuclear cell infiltration & $176(79.6)$ & $192(86.9)$ \\
\hline Vacuolization of hepatocyte & $45(20.4)$ & $47 \quad(21.3)$ \\
\hline Inclusion body in hepatocyte & $13(5.9)$ & $10(4.5)$ \\
\hline Necrosis of hepatocyte & $14(6.3)$ & $6(2.7)$ \\
\hline Pigmentation of sinusoidal cell & $42(19.0)$ & $32(14.5)$ \\
\hline Gallbladder & $\mathrm{n}=221$ & $\mathrm{n}=220$ \\
\hline Mononuclear cell infiltration & $32(14.5)$ & $26(11.8)$ \\
\hline Tongue & $\mathrm{n}=209$ & $\mathrm{n}=209$ \\
\hline Mononuclear cell infiltration & $41(19.6)$ & $37 \quad(17.7)$ \\
\hline Esophagus & $\mathrm{n}=157$ & $\mathrm{n}=156$ \\
\hline Mononuclear cell infiltration & $28(17.8)$ & $25(16.0)$ \\
\hline Stomach & $\mathrm{n}=221$ & $\mathrm{n}=221$ \\
\hline Mononuclear cell infiltration & $81(36.7)^{* *}$ & $44 \quad(19.9)$ \\
\hline Dilatation of gastric gland & $19(8.6)$ & $16(7.2)$ \\
\hline Duodenum & $\mathrm{n}=157$ & $\mathrm{n}=157$ \\
\hline Mononuclear cell infiltration & $19(12.1)$ & $13(8.3)$ \\
\hline Pigmentation & $40(25.5)$ & $40 \quad(25.5)$ \\
\hline Small intestine & $\mathrm{n}=221$ & $\mathrm{n}=221$ \\
\hline Mononuclear cell infiltration & $23(10.4)$ & $23(10.4)$ \\
\hline Large intestine & $\mathrm{n}=221$ & $\mathrm{n}=220$ \\
\hline Mononuclear cell infiltration & $20(9.0)$ & $34(15.5)$ \\
\hline Pigmentation & $17(7.7)$ & $28 \quad(12.7)$ \\
\hline Submandibular gland & $\mathrm{n}=221$ & $\mathrm{n}=221$ \\
\hline Mononuclear cell infiltration & $113(51.1)$ & $113(51.1)$ \\
\hline Sublingual gland & $\mathrm{n}=157$ & $\mathrm{n}=157$ \\
\hline Mononuclear cell infiltration & $59(37.6)$ & $51(32.5)$ \\
\hline Pancreas & $\mathrm{n}=221$ & $\mathrm{n}=221$ \\
\hline Mononuclear cell infiltration & $21(9.5)$ & $19(8.6)$ \\
\hline Kidney & $\mathrm{n}=221$ & $\mathrm{n}=221$ \\
\hline Pigmentation of tubular epithelium & $56(25.3)$ & $42(19.0)$ \\
\hline Basophilic tubular epithelium & $35(15.8)$ & $33(14.9)$ \\
\hline Calcium deposition in papilla & $16(7.2)$ & $20(9.0)$ \\
\hline Dilatation of tubule & $12(5.4)$ & $15(6.8)$ \\
\hline Vacuolization of tubular epithelium & $18(8.1)^{*}$ & $7(3.2)$ \\
\hline Hyaline cast & $11(5.0)$ & $9(4.1)$ \\
\hline Glomerulosclerosis & $10(4.5)$ & $14(6.3)$ \\
\hline Mononuclear cell infiltration & $143(64.7)$ & $125(56.6)$ \\
\hline Urinary bladder & $\mathrm{n}=221$ & $\mathrm{n}=220$ \\
\hline Mononuclear cell infiltration & $34(15.4)$ & $36(16.4)$ \\
\hline Eosinophilic inclusion in epithelium & $29(13.1)$ & $35(15.9)$ \\
\hline
\end{tabular}


Table 2. Incidnce of spontaneous histopathological lesions in cynomolgus monkeys (continued)

\begin{tabular}{|c|c|c|}
\hline & Male $(\%)$ & Female $(\%)$ \\
\hline Heart & $\mathrm{n}=221$ & $\mathrm{n}=221$ \\
\hline Mononuclear cell infiltration & $97 \quad(43.9)$ & $91(41.2)$ \\
\hline Pigmentation & $3(1.4)$ & $2(0.9)$ \\
\hline Coronary arteritis & $1(0.5)$ & 0 \\
\hline Lung & $\mathrm{n}=221$ & $\mathrm{n}=221$ \\
\hline Pigmentation & $141(63.8)$ & $150(67.9)$ \\
\hline Mononuclear cell infiltration & $65(29.4)$ & $61(27.6)$ \\
\hline Aggregation of macrophage & $21(9.5)$ & $17(7.7)$ \\
\hline Granuloma & $14(6.3)$ & $13(5.9)$ \\
\hline Emphysema & $16(7.2)^{*}$ & $6(2.7)$ \\
\hline Spleen & $\mathrm{n}=221$ & $\mathrm{n}=221$ \\
\hline Hyaline deposition & $43(19.5)$ & $40(18.1)$ \\
\hline Hypertrophy of follicle & $11(5.0)$ & $9(4.1)$ \\
\hline Pigmentation & $25(11.3)$ & $23(10.4)$ \\
\hline Congestion & $11(5.0)$ & $13(5.9)$ \\
\hline Bone marrow & $\mathrm{n}=221$ & $\mathrm{n}=221$ \\
\hline Lymphoid follicle & $19(8.6)$ & $27(12.2)$ \\
\hline Thymus & $\mathrm{n}=216$ & $\mathrm{n}=219$ \\
\hline Involution & $63(29.2)$ & $58(26.5)$ \\
\hline Cyst & $52(24.1)$ & $40(18.3)$ \\
\hline Mesenteric lymph node & $\mathrm{n}=221$ & $\mathrm{n}=221$ \\
\hline Pigmentation & $21(9.5)^{* *}$ & $45(20.4)$ \\
\hline Hyaline deposition & $15(6.8)$ & $15(6.8)$ \\
\hline Testis & $\mathrm{n}=221$ & \\
\hline Atrophy of seminiferous tubule & $11(5.0)$ & \\
\hline Immature seminiferous tubule & $15(6.8)$ & \\
\hline Multinucleated giant cell & $5(2.3)$ & \\
\hline Prostate & $\mathrm{n}=221$ & \\
\hline Mononuclear cell infiltration & $76(34.4)$ & \\
\hline Ovary & & $\mathrm{n}=221$ \\
\hline Calcium deposition & & $18(8.1)$ \\
\hline Uterus & & $\mathrm{n}=221$ \\
\hline Mononuclear cell infiltration & & $21(9.5)$ \\
\hline Vagina & & $\mathrm{n}=157$ \\
\hline Mononuclear cell infiltration & & $54(34.4)$ \\
\hline Brain & $\mathrm{n}=221$ & $\mathrm{n}=221$ \\
\hline Pigmentation & $28(12.7)$ & $24(10.9)$ \\
\hline Calcium deposition & $8(3.6)$ & $10(4.5)$ \\
\hline Eye & $\mathrm{n}=209$ & $\mathrm{n}=209$ \\
\hline Mononuclear cell infiltration & $6(2.9)$ & $4(1.9)$ \\
\hline Skin & $\mathrm{n}=157$ & $\mathrm{n}=157$ \\
\hline Mononuclear cell infiltration & $3(1.9)$ & 0 \\
\hline Granuloma & $1(0.6)$ & $1(0.6)$ \\
\hline
\end{tabular}


Table 2. Incidnce of spontaneous histopathological lesions in cynomolgus monkeys (continued)

\begin{tabular}{lcc}
\hline & Male $(\%)$ & Female $(\%)$ \\
\hline Pituitary & $\mathrm{n}=209$ & $\mathrm{n}=209$ \\
Cyst & $11(5.3)$ & $15(7.2)$ \\
Adrenal & $\mathrm{n}=221$ & $\mathrm{n}=221$ \\
Mononuclear cell infiltration & $14(6.3)$ & $16(7.2)$ \\
Pigmentation & $24(10.9)$ & $17(7.7)$ \\
Thyroid & $\mathrm{n}=221$ & $\mathrm{n}=221$ \\
Mononuclear cell infiltration & $18(8.1)$ & $18(8.1)$ \\
Pigmentation & $25(11.3)$ & $21(9.5)$ \\
Cystic dilatation of follicle & $9(4.1)$ & $8(3.6)$ \\
\hline
\end{tabular}

* : Significant difference in incidence between male and female $(p<0.05)$.

** : Significant difference in incidence between male and female $(p<0.01)$.

\section{Results}

Incidence of spontaneous lesions, except for hyperplastic, neoplastic or parasitic lesions, observed in each organ and their incidences are shown in Table 2.

A. Non-neoplastic, non-parasitic lesions

1. Alimentary system : In the liver, infiltration of mononuclear cells, such as lymphocytes or plasma celk, was most commonly observed in the hepatic lobules, and the incidence was high : $79.6 \%$ of the males and $86.9 \%$ of the females. Among the changes in the hepatocytes, vacuolization (Fig. 1) which is considered to be fatty change was most common (male, 20.4 $\%$; female, $21.3 \%$ ). This finding was almost always seen focally, however its localization in a hepatic lobule was not definite. Eosinophilic inclusion bodies in hepatocytes (male, $5.9 \%$; female, $4.5 \%$ ) and focal necrosis of hepatocytes (male, 6.3\% ; female, 2.7\%) (Fig. 2) were seen but at lower incidences. Deposition of brown pigment, which was positive for Berlin blue stain, was observed in sinusoidal cells at a relatively high frequency (male, 19.0\%; female, $14.5 \%$ ).

In the alimentary tract from the tongue through the large intestine, infiltration of mononuclear cells was observed in the lamina propria or subserosa at the incidence of $8.3 \%$ to $36.7 \%$. Dilatation of the gastric gland (male, $8.6 \%$; female, $7.2 \%$ ), deposition of yellowish brown pigment in the lamina propria of the duodenum (25.5\% in each sex), and deposition of brown pigment in the large intestine (male, $7.7 \%$; female, 12.7\%) were observed. The pigment in the duodenum was negative for Berlin blue stain, however that in the large intestine was positive. In the submaxillary gland, sublingual gland, and pancreas, infiltration of mononuclear cells was also observed.

2. Urinary system : In the kidney, incidence of the tubular lesions was higher than one of the glomerular lesion. Deposition of brown pigment which was positive for Berlin blue stain in the tubular epithelia (male, 25.3\%; female, 19.0\%) (Fig. 3) and basophilic tubular epithelia (male, 15.8\% ; female, 14.9\%) were observed frequently. Calcium deposition in papilla (male, $7.2 \%$; female, 9.0\%) (Fig. 4), dilatation of the renal tubules (male, $5.4 \%$; female, $6.8 \%$ ), vacuolization of the tubular epithelia (male, $8.1 \%$; female, $3.2 \%$ ), and hyaline casts (male, $5.0 \%$; female, $4.1 \%$ ) were observed in a small number of animals. Infiltration of mononuclear cells in the interstitial tissue was observed frequently (male, 64.7\% ; female, 56.6\%).

3. Cardiovascular system : In the heart, infiltration of mononuclear cells was observed frequently (male, $43.9 \%$; female, $41.2 \%$ ); pigmentation (male, $1.4 \%$; female, $0.9 \%$ ) and coronary arteritis (male, $0.5 \%$ ) were observed in a few animals.

4. Respiratory system : In the lung, deposition of dark-brown pigment in the interstitial tissue was most cost common (male, $63.8 \%$; female, $67.9 \%$ ). Infiltration of mononuclear cells in the interstitial tissuse (male, 29.4\% ; female $27.6 \%$ ), accumulation of macrophages 
Table 3. Incidence of hyperplastic or neoplatic lesions in cynomolgus monkeys

\begin{tabular}{llcc}
\hline \multicolumn{1}{c}{ Organ } & \multicolumn{1}{c}{ Finding } & Male $(\%)$ & Female $(\%)$ \\
\hline Gallbladder & Hyperplasia of epithelium & 0 & $1(0.5)$ \\
Tongue & Papillary hyperplasia of epithelium & $1(0.5)$ & 0 \\
Stomach & Polyp & $1(0.5)$ & $1(0.5)$ \\
Ovary & Teratoma & & $1(0.5)$ \\
Uterus & Papillary hyperplasia of endometrium & & $1(0.5)$ \\
Adrenal & $\begin{array}{l}\text { Nodular hyperplasia of zona fascicularis } \\
\text { cells }\end{array}$ & $10(4.5)$ & $3(1.4)$ \\
\hline
\end{tabular}

in the alveoli (male, $9.5 \%$; female, $7.7 \%$ ), and granuloma (male, $6.3 \%$; female, $5.9 \%$ ) were observed.

5. Hematopoietic system : In the spleen, hyaline deposition (male, 19.5\% ; female, 18.1 $\%)$ and hypertrophy of lymphoid follicles (male, 5.0\% ; female, $4.1 \%$ ) were seen in the white pulp, and deposition of brown pigment, which was positive for Berlin blue stain (male, $11.3 \%$; female, 10.4\%) were observed in the red pulp.

In the bone marrow, formation of lymphoid follicles was observed frequently (male, $8.6 \%$; female, 12.2\%) (Fig. 5). In the thymus, involution (atrophy of both the cortex and medulla) (male, 29.2\% ; female, 26.5\%) and cysts (male, $24.1 \%$; female, 18.3\%) (Fig. 6) were of ten seen. In the mesenteric lymph node, pigmentation in the medullary cord (male, $9.5 \%$; female, 20.4 \%) and hyaline deposition in lymphoid follicles (6.8\% in each sex) were observed.

6. Genital system : In the testis, immature seminiferous tubules $(6.8 \%)$ and multinucleated giant cells in the seminiferous tubules (2.3 $\%$ ) (Fig. 7 ) were observed. In the ovary, calcium deposition (8.1\%) (Fig. 8) was observed.

7. Nervous system : In the brain, deposition of brown pigment was observed at a fairly high frequency (male, 12.7\% ; female, 10.9\%) (Fig. 9). The pigment was positive for Masson stain, ferrous ion uptake method, and Nile blue stain, and bleached by potassium permanganate-oxalic acid, while it was negative for either PAS reaction or Berlin blue stain, and emitted no autofluorescence with ultraviolet radiation. The cells retaining pigment with radial cytoplasmic projections were positive for GFAP. Most of the lesions were observed in the cortex of the frontal or parietal lobes. In the diencephalon, calcium deposition was seen around the small blood vessels (male, 3.6
$\%$; female, 4.5\%) (Fig. 10).

8. Endocrine system : In the pituitary, cysts were observed in the anterior or intermediate lobe (male, 5.3\% ; female 7.2\%). Pigmentation of the zona reticularis celle male, $10.9 \%$; female, $7.7 \%$ ) in the adrenal and of the follicular epithelia (male, $11.3 \%$; female, $9.5 \%$ ) in the thyroid were observed.

B. Hyperplastic and neoplastic lesions

Incidence of hyperplastic or neoplastic lesions is shown in Table 3.

The most frequent hyperplastic lesion was nodular hyperplasia of the zona fascicularis cells in the adrenal (male, $4.5 \%$; female, 1.4 \%) (Fig. 11). Hyperplasia of epithelia in the gallbladder (female, 0.5\%), papillary hyperplasia of mucosa in the tongue (male, $0.5 \%$ ), polyps in the stomach ( $0.5 \%$ in each sex), and papillary hyperplasia of the endometrium $(0.5$ $\%)$ were rarely observed. The only neoplastic lesion was a teratoma observed in the left ovary of one female. The teratoma was like a cyst $(2 \times 2 \times 1.5 \mathrm{~cm})$ with black spots and contained hair and a mucous substance. In the wall of the cyst, mature tissues of bone, bone marrow, cartilage, tooth, skin, and hair follicle were observed (Fig. 12).

\section{Parasitic lesions}

Incidence of lesions related to parasites is shown in Table 4.

In the liver, granulomas were seen in 12.7 $\%$ of the males and $17.2 \%$ of the females. The granulomas were cysts with a thick wall consisting of fibroblasts, epithelioid cells, lymphocytes and eosinophils, contained an amorphous substance (Fig. 13), and ware frequently calcified. Helminths with a sucker were seen in the intrahepatic bile ducts (male, $1.4 \%$; female, $0.9 \%$ ), however no changes were observed in the hepatic parenchyma.

In the large intestine, large cystic granu- 
Table 4. Incidence of spontaneous lesions related to parasites in cynomolgus monkeys

\begin{tabular}{llrr}
\hline Organ & Finding & Male $(\%)$ & Female $(\%)$ \\
\hline Liver & Parasitic granuloma & $28(12.7)$ & $38(17.2)$ \\
& Parasite in bile duct & $3(1.4)$ & $2(0.9)$ \\
Tongue & Parasite in muscle fiber & $25(12.0)$ & $36(17.2)$ \\
& Parasitic granuloma & $2(1.0)$ & 0 \\
Esophagus & Parasite in muscle fiber & $1(0.6)$ & $1(0.6)$ \\
& Parasitic granuloma & $1(0.6)$ & 0 \\
Stomach & Parasitic granuloma & $10(4.5)$ & $12(5.4)$ \\
& Hyperplasia of epithelium with parasite in lumen & $1(0.5)$ & $1(0.5)$ \\
Small intestine & Parasitic granuloma & 0 & $1(0.5)$ \\
& Parasite in omentum & $1(0.5)$ & $1(0.5)$ \\
Large intestine & Parasitic granuloma & $71(32.1)$ & $66(30.0)$ \\
& Parasite in lumen & $2(0.9)$ & $1(0.5)$ \\
Lung & Parasite/Parasitic granuloma & $12(5.4)$ & $13(5.9)$ \\
Spleen & Parasitic granuloma & $3(1.4)$ & $1(0.5)$ \\
Thymus & Parasite & $1(0.5)$ & $3(1.4)$ \\
Mesenteric & Parasitic granuloma & $2(0.9)$ & $1(0.5)$ \\
\multicolumn{1}{c}{ lymph node } & & &
\end{tabular}

Table 5. Number of animals with parasitic lesion (s)

\begin{tabular}{cccccc}
\hline $\begin{array}{c}\text { Number of Parasitic } \\
\text { Lesion(s) / Animal }\end{array}$ & 1 & 2 & 3 & 4 & 5 \\
\hline Male & 78 & $22(1)$ & $9(2)$ & 1 & 0 \\
Female & 75 & $22(1)$ & 6 & 3 & 1 \\
\hline
\end{tabular}

( ) : Number of animals with the same lesion in 2 or 3 organs.

lomas were seen in the lamina propria, submucosa, or muscularis (male, $32.1 \%$; female, 30.0\%) (Fig. 14). The inner side of the granulomas were covered by multinucleated giant cells and contained threadworms and an amorphous substance.

In the stomach, papillary hyperplasia of the mucosa was observed in $0.5 \%$ in each sex, and helminths were found in the gastric pits in the lesions (Fig. 15). Another parasitic lesion was a granuloma consisting of fibrous tissue in the subserosa (male, $4.5 \%$; female, $5.4 \%$ ), however the presence of helminth was not confirmed. The same granulomas were observed in the subserosa of the small intestine (male, $0.5 \%)$ and in the omentum ( $0.5 \%$ in each sex $)$.

In the lung, a granuloma accompanied by necrosis of the parenchyma around mites and wide-spreaded infiltration of inflammatory cells was seen in $5.4 \%$ of the males and $5.9 \%$ of the females (Fig. 16).

In the spleen, a granuloma accompanied by proliferation of reticuloendothelial cells and infiltration of eosinophils was observed in $1.4 \%$ of the males and $0.5 \%$ of the females. Microfilariae, occasionally engulfed by multinucleated giant cells were found in the granulomas.

Cysts of sporozoon were observed in the 
muscle fibers of the tongue (male, 12.0\%; female, $17.2 \%$ ), esophagus (female, $0.6 \%$ ), prostate $(0.5 \%)$, and subcutaneous tissus (male, $2.5 \%$; female, $0.6 \%$ ), however no biological reaction against the parasites was observed.

Number of animals with parasitic lesions is shown in Table 5. Individually, a few animals had 4 or 5 parasitic lesions although most of animals had single lesion. A small number of animals had same parasitic lesion, cysts of sporozoon, in 2 or 3 organs individually.

\section{Discussion}

The liver and kidney are the organs in which toxic effects of chemicals are induced frequently, because in many cases a drug is metabolized in the liver and excreted in the urine via the kidney. Therefore, it is noteworthy that many spontaneous lesions occur in these organs : infiltration of mononuclear cells was most common in both organs, and vacuolization of the hepatocytes, dilatation of the renal tubules, vacuolization of the renal tubular epithelia were observed to a lesser extent. Care must be taken to differentiate the spontaneous infiltration of mononuclear cells in the liver from the obvious hepatitis which can be caused by the administration of chemicals such as diphenylhydantoin [23] and para-aminosalicylic acid [14]. The storage of proteins [4] or fat droplets [27] in alcoholism and the storage of fat droplets with tetracycline treatment $[5,8]$ or exposure to carbon tetrachloride [22] are observed histopathologically as vacuolization of hepatocytes. Therefore, it is important to observe the size and/or distribution of the fat droplets in the lobulus and the presence or absence of degeneration or necrosis of hepatocytes or inflammatous changes in order to distinguish a toxic change from a spontaneous one. In a few animals, focal necrosis of hepatocytes was observed along with infiltration of mononuclear cells and multinucleated giant cells. The lesions were similar to those seen in parasitism by Hepatocystis spp. ; however, a definitive diagnosis could not be made because the lesions were not identified a typical lesion caused by Hepatocystis spp. Dilatation of the renal tubules by cephaloridine [31] is easily distinguished from spontaneous dilatation because degenerative changes in the renal epithelia are accompanied in the case of drug-induced dilatation but not spontaneous dilatation. Vacuolization of the renal tubular epithelia caused by exposure to carbon tetrachloride [13] can be distinguished from spontaneous vacuolization by the presence of degenerative changes.

In various organs, deposition of yellowish to dark brown pigment was observed. The brown pigment in the hepatic sinusoidal cells, renal tubular epithelia, splenic red pulp, and around parasitic granulomas in the large intestine was positive for Berlin blue stain, indicating deposition of hemosiderin. The yellowish brown pigment in the duodenal lamina propria and mesenteric lymph node was negative with Berlin blue stain, indicating probably deposition of bile pigment. The dark brown pigment seen in the interstitial connective tissue around the lung bronchioles resembles the pigment seen in anthracosis in humans ; the pigment in the lungs of monkeys is reported to be a discharge of lung mites, Pneumonysus sp. [12]. The brown pigment in the brain was considered to be melanin because of a positive reaction with Masson stain for argentophile granules [19], ferrous ion uptake [16], positive Nile blue staining [15], bleaching by potassium permanganate-oxalic acid [17], a negative PAS reaction [20], negative Berlin blue staining [7], and no autofluorescence upon ultraviolet radiation [34]. Since the cells retaining the melanin-like pigment had radial cytoplasmic projections and gave a positive GFAP immunohistochemical stain, they are considered to be astrocytes. Astrocytes have no phagocytic ability [21], and the lesions were located far from the substantia nigra and the locus coeruleus. Therefore, it is considered that the melanin pigment is produced by astrocytes. Neuronal melanin $[3,6,9,18,21,29]$ or neuronal ceroid-lipofuscin $[1,11,33]$ have been reported in mammals, including monkeys, as brown pigment in the central nervous system, however melanin pigment has not been reported in the astrocytes. On the other hand, difficulty in identifying the substance producing the brown pigmentation in $\mathrm{H}-\mathrm{E}$ stained sections of various organs emphasized the importance of histochemical techniques.

Statistically significant sex differences were seen in the incidence of infiltration of mononuclear cells in the stomach $(p<0.01)$, pigmentation in the mesenteric lymph node ( $p$ 
$<0.01)$, and vacuolization of the renal tubular epithelia $(p<0.05)$; however, the meaning of the sex differences in these changes is not clear as there are no reports of the involvement of sex hormones in these changes.

Reports of neoplastic lesions in monkeys are rare, and a teratoma of the ovary was observed in one female in this study. The teratoma formed a cyst containing hair and a mucous substance. In the wall of the cyst, ectodermal tissues such as tooth, skin, and hair follicle and mesodermal tissues such as bone, cartilage, and bone marrow were observed histologically, indicating a bidermoma. Scott et al. [30] and Ninomiya [25] reported this tumor in the ovary of a rhesus monkey and in the adrenal of a Wistar rat, respectively. The former was a dermoid cyst consisting of only ectodermal tissues such as skin, sweat gland, and hair follicle; the latter was a tridermoma consisting of ectodermal tissues such as nervous tissue and skin, mesodermal tissue such as striated muscle, bone, and cartilage, and endodermal tissues such as pancreatic acinus.

The most common parasitic lesion in this study was a cystic granuloma in the large intestine with an incidence of more than $30 \%$ in each sex. Since a threadworm was often found in the cyst, the lesion is considered to be formed by a larva (in the third phase) of Oesophagostomum sp. [2]. In the liver, cystlike granulomas consisting of fibroblasts, epithelioid cells, lymphocytes, and eosinophils were frequently observed. Though no parasite was observed in these granulomas in most cases, they are considered to be related to schizogony of Hepatocystis spp. because their morphology is similar to that in one of the cases reported by Ryan et al. [28]. Threadworms, considered to be Noctia nocti, were found in the gastric pits with papillary hyperplasia of the regional mucosa in one animal of each sex. Hashimoto et al. [10], observed papillomas caused by threadworms in the stomach at a relatively high frequency. We observed fibrous granulomas without evidence of parasites in the subserosa of the stomach, small intestine, and mesenterium. Abbott et al. [2] reported a relationship between similar lesions and peritoneal migration of Paragonimus westermani; therefore, the granulomas might be related to Paragonimus westermani or other parasites. In the spleen of a few animals, granulomas with microfilariae and proliferation of reticuloendothelial cells were observed. Nonoyama et al. [26] and Narama et al. [24], reported the presence of mature filariae under the peritoneum or pleura in cynomolgus monkeys with similar splenic lesions, and Tada et al. [32] identified morphologically a mature filaria and microfilariae in the blood as Edesonfilaria malayensis. In this study, no mature filariae were found at autopsy, however the granuloma in the spleen is considered to related to Edesonfilaria malayensis, because the histological features are similar to those in one of the cases in the reports of Nonoyama et al. and Narama et al. Though several other parasitic lesions were observed, they would not affect the interpretation of chemical toxicity, because no abnormalities were seen in any animal in general condition, hematology, or blood chemistry. Nevertheless, there is the possibility of misinterpretation when no parasites are detected or only inflammatory lesions around a parasite are observed. Therefore, it isnecessary to accumulate knowledge about parasitic lesions or to perform three-dimentional observation of serial sections.

\section{References}

[1] Abbott, D. P. and Edmondson, N. A. (1983). Neuronal ceroid-lipofuscin storage in a cynomolgus monkey (Macaca fascicularis). Lab. Anim, 17, 18-20.

[2] Abbott, D. P. and Majeed, S. K. (1984). A survey of parasitic lesions in wild-caught, laboratory-maintained primates : (Rhesus, cynomolgus, and baboon). Vet. Pathol, 21, 198-207.

[3] Adler, A. (1942). Melanin pigment in the brain of the gorilla. J. Comp. Neurol, 76, 501-507.

[4] Baraona, E., Leo, M. A., Borowsky, S. A., and Lieber, C. S. (1977) Pathogenesis of alcohol-induced accumulation of protein in the liver, J. Clin. Invest.,60, $546-554$

[5] Breen, K. J., Schenker, S., and Heimberg, M. (1975). Fatty liver induced by tetracycline in the rat. Gastroenterology, 69, 714-723.

[6] Brown, J. O. (1943). Pigmentation of substantia nigra and locus coeruleus in certain carnivores. J. Comp. Neurol, 79, 393-405.

[7] Bunting, H. (1949). The histochemical detection of iron in tissues. Stain Technol, 24, 109-115.

[8] Combes, B., Whalley, P. J., and Adams, R. H. (1972). Tetracycline and the liver. Progr. Liver Dis. 4, 589596.

[9] Gillilan, L. A. (1943). The nuclear pattern of the non-tectal portions of the midbrain and isthmus in ungulates. J. Comp Neurol, 78, 289-364.

[10] Hashimoto, I. and Honjo, S. (1966). Survey of 
helminth parasites in cynomolgus monkeys (Macaca irus). Jpn J. Med Sci Biol, 19, 218.

[11] Hoover, D. M., Little, P. B., and Cole, W. D. (1984). Neuronal ceroid-lipofuscinosis in a mature dog. Vet. Pathol, 21, 359-361.

[12] Innes, J. R. M. and Hull, W. B. S. (1972). Endoparasites-Lung mites. In Pathology of Simian Parasites, Part II : Infectious and Parasitic Diseases, pp 177-193, T-W-Fiennes, R. N. (ed), Karger, Basel.

[13] Jennings, R. B. and Kearns, W. M. (1953). Necrotizing nephrosis in the rat following administration of carbon tetrachloride. Arch Pathol, 56, 348-359.

[14] Lichtenstein, M. R. and Cannemeyer, W. (1953). Severe para-aminosalicylic acid hypersensitivity simulating mononucleosis or hepatitis. J. Am Med Assoc., 152, 606-607.

[15] Lillie, R. D. (1956). A Nile blue staining technic for the differentiation of melanin and lipofuscins. Stain Technol, 31, 151-153.

[16] Lillie, R. D. (1957). Ferrous ion uptake. A specific reaction of the melanins. Arch Pathol, 64, 100-103.

[17] Lillie, R. D. (1957). Trichoxanthin, the yellow granular pigment of guinea pig hair follicles and hairs. J. Histochem Cytochem, 5, 346-353.

[18] Marsden, C. D. (1969). Brain melanin. In Pigment in Pathology, pp 395-420, Academic Press, New York and London.

[19] Masson, P. (1928). Carcinoids (argentaffin-cell tumors) and nerve hyperplasia of the appendicular mucosa. Am J. Pathol, 4, 181-231.

[20] McManus, J. F. A. (1948). Histological and histochemical uses of periodic acid. Stain Technol, 23, 99-108.

[21] McMenemey, W. H. (1979). The central nervous system. In Systemic Pathology, 2 nd ed. Vol. 5, pp 2077-2294, Churchil Livingstone, Edinburgh, London and New York.

[22] Moon, H. D. (1972). The pathology of fatal carbon tetrachloride poisoning with special reference to the histogenesis of the hepatic and renal lesion. Am J. Pathol, 26, 1041-1057.

[23] Mullick, F. G. and Ishak, K. G. (1980). Hepatic injury associated with diphenylhydantoin therapy : A clinicopathologic study of 20 cases. Am J. Clin Pathol, 74, 442-452.
[24] Narama, I., Miura, K., Tsuruta, M., and Tsuchitani, M. (1985). Microfilarial granulomas in the spleens of wild-caught cynomolgus monkeys (Macaca fascicularis). Vet. Pathol, 22, 355-362.

[35] Ninomiya, H. (1983). Spontaneous teratoma in a Wistar rat. Exp. Anim, 32, 145-149.

[26] Nonoyama, T., Sugitani, T., Orita, S., and Miyajima, H. (1984). A pathological study in cynomolgus monkeys infected with Edesonfilaria malayensis. Lab. Anim Sci, 34, 604-609.

[27] Popper, H. and Lieber, C. S. (1980). Histogenesis of alcoholic fibrosis and cirrhosis in the baboon. Am J. Puthol, 98, 695-716.

[28] Ryan, M. J., Cousins, O. B., and Bhandari, C. (1986). Diagnostic exercise : Hepatic granulomas in a cynomolgus monkey. Lab. Anim Sci, 36, 56-58.

[29] Scherer, H. J. (1939). Melanin pigmentation of the substantia nigra in primates. J. Comp. Neurol, 71, 91-98.

[30] Scott, W. J., Fradkin, R., and Wilson, J. G. (1975). Ovarian teratoma in a rhesus monkey. $J$ med Primatol, 4, 204-206.

[31] Silverblatt, F., Turck, M., and Bulger, R. (1970). Nephrotoxicity due to cephaloridine : A light-and electron-microscopic study in rabbits. J. Infect. Dis, 122, 33-43.

[32] Tada, M., Sugitani, T., Orita, S., Akita, T., Miyajima, H., and Imai, A. (1983). Identification of Edesonfilaria malayensis from cynomolgus monkeys (Macac a fascicularis), and description of the microfilaria. Jpn. J. Parasit., 32, 509-515.

[33] Vandevelde, M. and Fatzer, R. (1980). Neuronal ceroid-lipofuscinosis in older dachshunds. Vet. Puthol, 17, 686-692.

[34] VanWoert, M. H., Prasad, K. N., and Borg, D. C. (1967). Spectroscopic studies of substantia nigra pigment in human subjects. $J$. Neurochem, 14, 707716.

[35] Yanagita, T. (1973). The use of monkeys in the evaluation of drug safety. In The Laboratory Animal in Drug Testing. 5 th Symposium of the International Committee on Laboratory Animals (ICLA), Hannover, 19-21 September, 1972, pp 177-184 Spiegel, A. (ed), Gustav Fischer Verlag, Stuttgart. 


\section{毒性試験に用いられたカニクイザルにおける \\ 自然発生病変}

伊藤隆康・茶谷文雄・佐々木 啓

安藤孝夫・宮嶌宏彰

武田薬品工業株式会社薬剤安全性研究所

\begin{abstract}
薬物による変化と自然発生病変との鑑別を正確に行 い, より精度の高い毒性評価を行らことを目的として， 毒性試験に用いられた雙雄各 221匹のカニクイザルの自 然発生病変について病理組織学的に検討した。肝蔵及び 腎蔵は毒性所見が多く発現する葴器であるが, 自然発生 病変もまた多く認められた。単核細胞浸潤, 肝細胞の空 胞化, 尿細管の払張, 尿細管上皮の空胞化が比較的高頻 度にみられたが，これらの所見は毒性変化として認めら れるものに類似していた。各種葴器において褐色調の色
\end{abstract}

素沈着が認められたが，その本態はへモジデリン，炭粉 あるいはメラニンと多様であった。また，野生で捕獲し た動物であるため寄生虫による病変が多数みられ, 特に 大腸と肝蔵に扣ける肉芽腫が高頻度に認められた。大腸 の肉芽腫では内腔に線虫の虫体を認める場合が多いのに 対し, 肝臓の肉芽腫では寄生虫は認められないため, 瘢 痕病変や周辺の炎症性病変のみ観察した場合毒性病変と 誤認する可能性が示唆された。

\section{Explanation of Figures}

Fig. 1. Liver, Female, Vacuolization of hepatocytes $\mathrm{H}-\mathrm{E}$ stain $\times 100$

Fig. 2. Liver, Male, Focal necrosis of hepatocytes with infiltration of multinuclear giant cells (arrows) and mononuclear cells $\mathrm{H}-\mathrm{E}$ stain $\times 200$

Fig. 3. Kidney, Female, Pigmentation of epithelial cells in proximal straight tubule (arrow) $\mathrm{H}-\mathrm{E}$ stain $\times 200$

Fig. 4. Kidney, Male, Deposition of calcium (arrow) in interstitial tissue of renal papilla $\mathrm{H}-\mathrm{E}$ stain $\times 200$

Fig. 5. Bone Marrow, Male, Formation of lymphoid follicle H-E stain $\times 100$

Fig. 6. Thymus, Male, Involution of thymus, and formation of cyst (arrow) $\mathrm{H}-\mathrm{E}$ stain $\times 40$

Fig. 7. Testis, Male Multinuclear giant cells (arrows) in seminiferous tubule $\mathrm{H}-\mathrm{E}$ stain $\times 200$

Fig. 8. Ovary, Female, Deposition of calcium in ovarian follicles (arrows) $\mathrm{H}-\mathrm{E}$ stain $\times 100$

Fig. 9. Cerebrum, Male Pigmentation of glial cells (arrows) $\mathrm{H}-\mathrm{E}$ stain $\times 200$

Fig. 10. Cerebrum, Male, Deposition of calcium (arow) around blood vessel $\mathrm{H}-\mathrm{E}$ stain $\times 200$

Fig. 11. Adrenal Gland, Male, Nodular hyperplasia $(\mathrm{N})$ of cortical cells in zona fasciculata $\mathrm{H}-\mathrm{E}$ stain $\times 100$

Fig. 12. Ovary, Female, Teratoma. In the wall of the cyst, mature tissues of tooth (T), bone (B), skin (S), and hair follicle (HF) are observed. H-E stain, $\times 15$

Fig. 13. Liver, Male, Parasitic granuloma beneath capsule $\mathrm{H}-\mathrm{E}$ stain $\times 20$

Fig. 14. Large Intestine, Male, Parasitic granuloma in submucosa $\mathrm{H}-\mathrm{E}$ stain $\times 20$

Fig. 15. Stomach, Male, Papillary hyperplasia of mucosa $\mathrm{H}-\mathrm{E}$ stain $\times 10$ Inset: Magnified photograph of the area surrounded by lines, $\times 40$ Parasites in gastric pits

Fig. 16. Lung, Male, Parasite (arrow) in bronchus, and granuloma with infiltration of inflammatory cells around the parasite $\mathrm{H}-\mathrm{E}$ stain $\times 20$ 


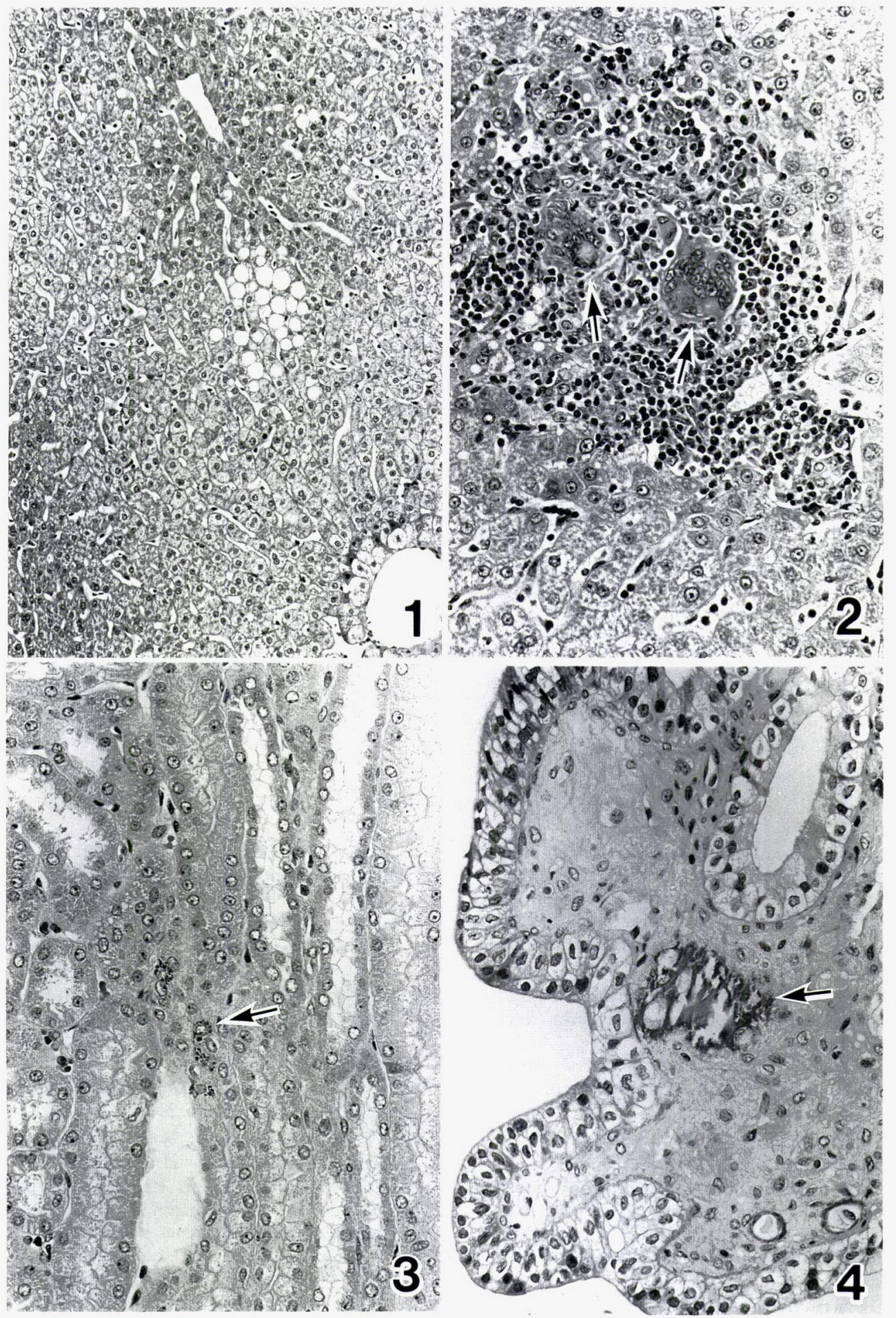




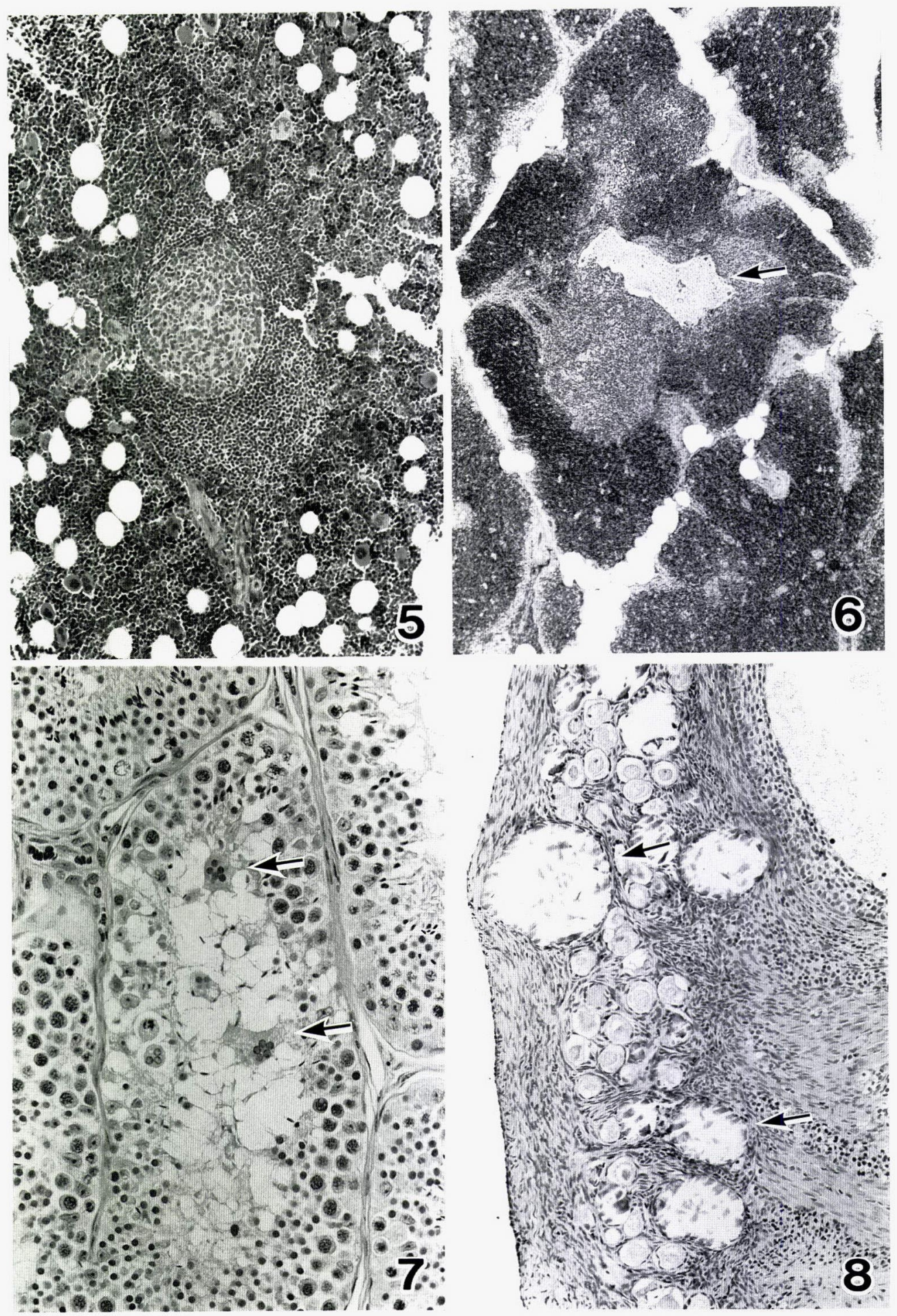



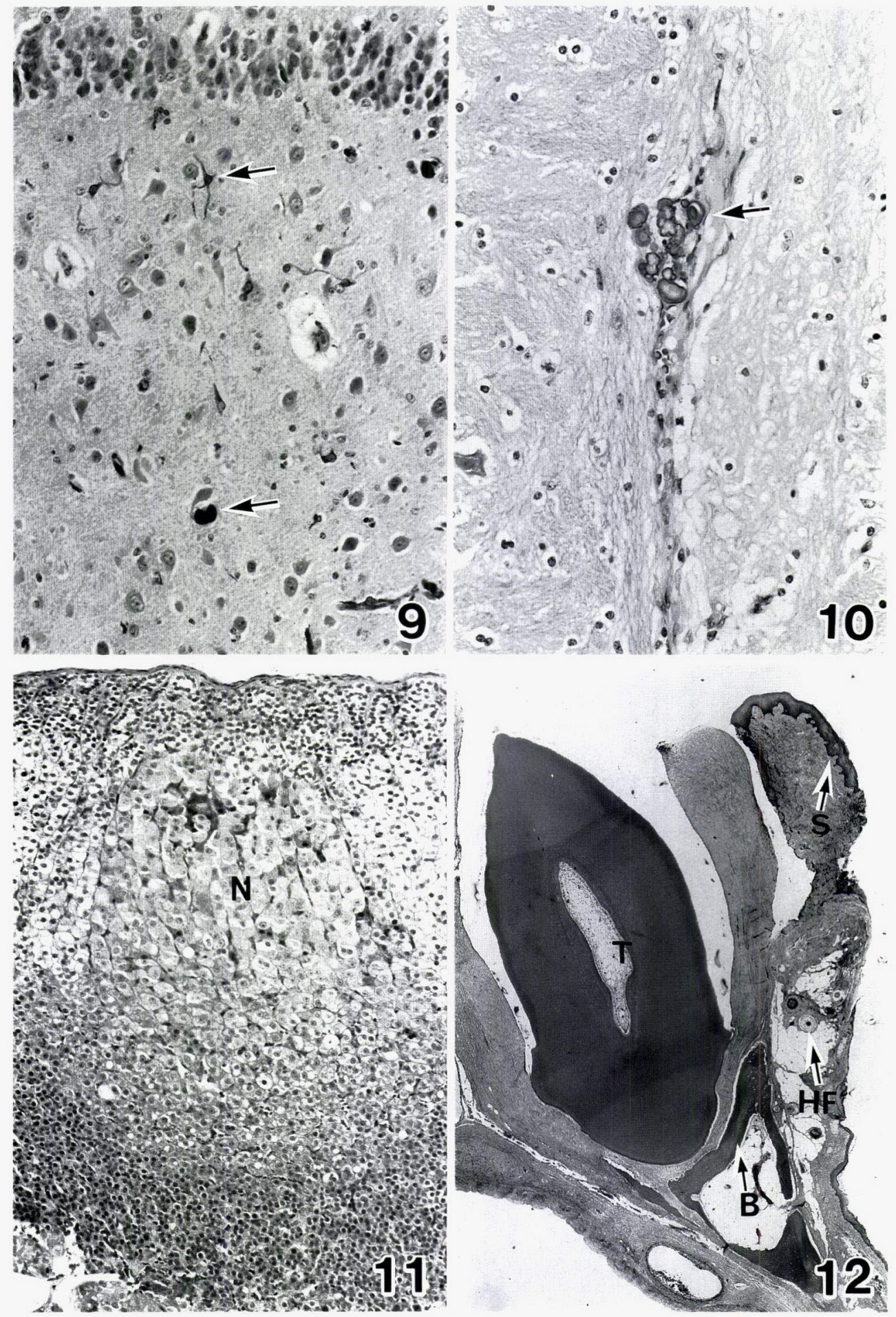

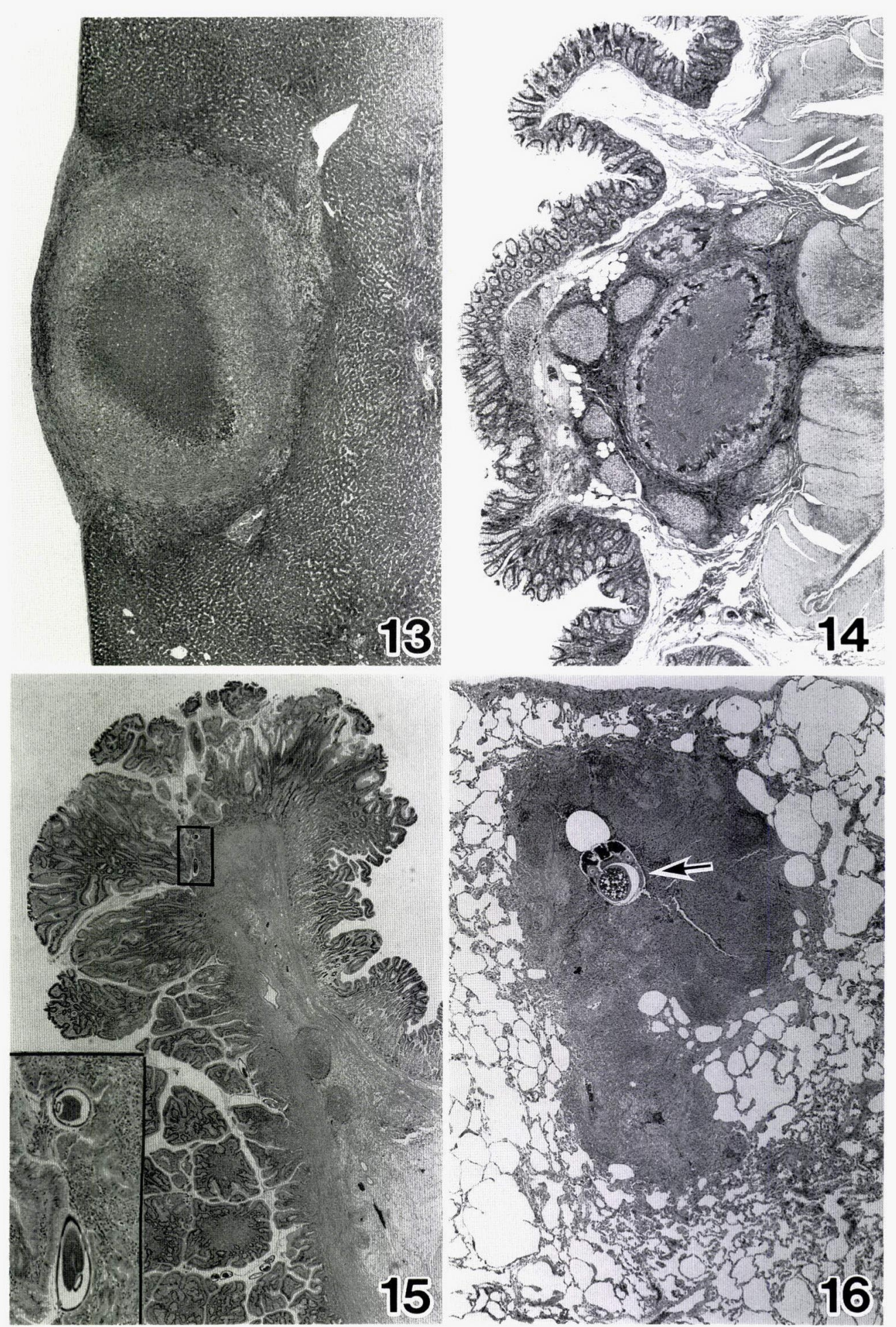